\title{
A Subtropical Nudibranch, Polycera hummi (Abbott 1952), Described for the First Time from Virginia
}

Wissan A. Jawad

Stacy A. Kruger-Hadfield

Paige G. Ross

Virginia Institute of Marine Science

Follow this and additional works at: https://scholarworks.wm.edu/vimsarticles

Part of the Marine Biology Commons, and the Zoology Commons

\section{Recommended Citation}

Jawad, Wissan A.; Kruger-Hadfield, Stacy A.; and Ross, Paige G., A Subtropical Nudibranch, Polycera hummi (Abbott 1952), Described for the First Time from Virginia (2021). Northeaster Naturalist, 28(2), N15-N23.

doi: $10.1656 / 045.028 .0211$

This Article is brought to you for free and open access by the Virginia Institute of Marine Science at W\&M ScholarWorks. It has been accepted for inclusion in VIMS Articles by an authorized administrator of W\&M ScholarWorks. For more information, please contact scholarworks@wm.edu. 


\title{
Notes of the Northeastern Naturalist, Issue 28/2, 2021
}

\section{A Subtropical Nudibranch, Polycera hummi (Abbott 1952), Described for the First Time from Virginia}

Wissam A. Jawad ${ }^{1, *}$, Stacy A. Krueger-Hadfield ${ }^{2}$, and P.G. Ross ${ }^{3}$

\begin{abstract}
We collected an individual Polycera hummi, a subtropical nudibranch, in association with a green macroalga Ulva sp. from an intertidal oyster reef in Burtons Bay, Wachapreague, VA. The established range of $P$. hummi is based solely on a handful of records from Mississippi and Florida in the Gulf of Mexico and the Carolinas in the Atlantic Ocean. This finding marks the highest latitude that this species has been found, $350 \mathrm{~km}$ north of its previously established range from Mississippi to Beaufort, NC. We observed the individual actively navigate the Ulva thallus which had encrusting bryozoans (unidentified genus) and arborescent bryozoans (Bugula sp.) - likely prey species. We briefly summarize the current knowledge on this rarely encountered nudibranch, provide information on the collection site, including other sea slugs often encountered in this area, note its behavior and interactions with macroalgae and bryozoans, and suggest some fruitful avenues of future work on the evolutionary ecology of rare nudibranch species like P. hummi.
\end{abstract}

Polycera nudibranchs are a colorful and globally distributed genus of dorids, with 61 currently described species found from temperate to tropical waters (Debelius and Kuiter 2007, Marshall et al. 2020). They have been reported from the eastern Atlantic (Calado and Silva 2012, Giacobbe and De Matteo 2013), western Atlantic (Debelius and Kuiter 2007, Ortea et al. 1999), eastern Pacific (Behrens and Hermosillo 2005, Pola et al. 2014), and western and southern Pacific (Gosliner 1980, Wilson 2006). Most Polycera species are small $(<5 \mathrm{~mm})$ and often encountered in intertidal or shallow subtidal areas associated with macroalgae or hard substrates. Several species have exceptionally wide geographic ranges, including P. tricolor Robilliard (Three-color Polycera) occurring from British Columbia to Baja California (Pola et al. 2014) and the putatively invasive species P. hedpethi Er. Marcus (Hedgpeth's Dorid) with its reported worldwide distribution (Giacobbe and De Matteo 2013). Despite their nearshore and sometimes wide latitudinal distribution, most Polycera species are elusive, with few reports apart from their original descriptions.

Along the coast of the western Atlantic, several species of Polycera have been reported from the Caribbean (Ortea et al. 1999), but only 3-P. chilluna Er. Marcus, P. aurisula Marcus, and P. hummi Abbott - have been described from the Gulf and eastern coasts of North America. Polycera hummi, in particular, was first reported and described by Abbott (1952) from 5 preserved and 1 live specimen collected at Alligator Harbor, FL. Marcus (1961) reported a single individual from Beaufort, NC. Eyster (1980) found 13 individuals during bryozoan collections of Bugula sp. from May to September in creeks in the North Inlet Estuary near Georgetown, SC. Interestingly teeth from Carolina-collected individuals differed from those from Florida: Floridian specimens had 5 regular denticles on their innermost marginal teeth, while those from the Carolinas had none (Eyster 1980). Finally, Fox and Ruppert (1985) reported P. hummi abundance and seasonality between 1981 and 1985 from various habitats near Georgetown and Charleston, SC. Numbers of individuals were not provided, but they were described as rare and uncommon at 5 of the 6 sites (Table 1). To the best of our

\footnotetext{
${ }^{1}$ Department of Biology, Louisiana State University, 202 Life Sciences Building, Baton Rouge, LA 70803. ${ }^{2}$ Department of Biology, The University of Alabama at Birmingham, 1300 University Boulevard, Birmingham, AL 35294. ${ }^{3}$ Eastern Shore Laboratory, Virginia Institute of Marine Science, William \& Mary, 40 Atlantic Avenue, Wachapreague, VA 23480. ${ }^{*}$ Corresponding author - wjawad1@1su.edu.

Manuscript Editor: Thomas Trott
} 
knowledge, these reports make up the only publications on P. hummi. There are, however, several invaluable, online museum records and unpublished community (= citizen) science reports for P. hummi (Table 2). Such non-peer reviewed reports are often the only source of information on the range and ecology for cryptic groups like nudibranchs.

Collection site. On 15 October 2020, we collected several foliose Ulva sp. thalli that were fixed (sensu Krueger-Hadfield et al. 2018) by a holdfast to shell hash in a tide pool ( salinity $=31 \mathrm{ppt}$, water temperature $=21.2^{\circ} \mathrm{C}$ ) at an intertidal oyster reef at the Hurley lease site in Burtons Bay $\left(37^{\circ} 36^{\prime} 20.5^{\prime \prime} \mathrm{N}, 7^{\circ} 37^{\prime} 34.1^{\prime \prime} \mathrm{W}\right), \sim 2.5 \mathrm{~km}$ from the Virginia Institute of Marine Science Eastern Shore Lab (VIMS ESL), Wachapreague, VA. Ulva taxonomy is in flux, with on-going species revisions (Steinhagen et al. 2019a, b), including specimens sampled from Virginia (S. Steinhagen, Department of Marine Sciences, University of Gothenburg, Sweden, pers. comm.). Thus, we refer to the bladed, foliose Ulva sampled in this study as Ulva sp. until the species designations are resolved. The Ulva specimens collected were small, bright green, and in good physiological condition. Little fouling was noted upon collection and was consistent with previous observations of fixed Ulva sp. thalli in this area (S.A. Krueger-Hadfield, pers. observ.).

Identifying a new nudibranch at this site is especially remarkable in part because the site was recently surveyed by researchers at VIMS without a sighting of this species. This specific reef was surveyed during late spring 2018-2020 as part of an ongoing Ecological Monitoring Program at VIMS ESL. Earlier surveys prior to this did not systematically enumerate invertebrate taxa in this area (P.G. Ross, unpubl. data). We collected 2 haphazard quadrats yearly $(25 \mathrm{~cm} \times 25 \mathrm{~cm} \times 15 \mathrm{~cm}$ deep). We rinsed samples on a 1-mm sieve and identified all retained macrofauna and macroflora to the lowest practical taxon. We also sampled 5 other nearby intertidal reefs in this manner during the same time periods. Additionally, we concurrently used a dredge to sample 3 nearby subtidal shell beds and processed the samples similarly. All reefs and shell beds sampled were within 1.3-5.6 km of the Hurley lease. We did not find any nudibranchs at any of the intertidal reef sites, including the Hurley lease site during this sampling (Ross and Snyder 2020; P.G. Ross and R.A. Snyder, unpubl. data), but a total of 27 nudibranchs were found subtidally at the shell bed sites: 20 Cariopsilla pharpa Er. Marcus and 7 Corambe obscura (A.E. Verrill) (Ross and Snyder 2020; P.G. Ross and R.A. Snyder, unpubl. data).

Notes on Polycera hummi from Virginia. We stored the collected Ulva specimens at 4 ${ }^{\circ} \mathrm{C}$ in an open polyethylene bag with a seawater-moistened paper towel for $\sim 18$ hours. We did not examine the Ulva thalli for invertebrates prior to shipping overnight from VIMS

Table 1. Polycera hummi observations made by Fox and Ruppert (1985) between 1981 and 1985 near Charleston (C) and Georgetown (G), SC. The authors noted that all collections were made "in the intertidal zone, but extends as far into the subtidal as arms, dip nets, and long-handled shovels can reach" Fox and Ruppert (1985:2). Collections in tidal creeks and sounds were usually made with otter trawls deployed from boats.

\begin{tabular}{lll} 
Collection location & Abundance & Seasonality \\
\hline C - Folly River pilling & Rare & Fall \\
C - Composite collection in nearby creeks and sounds & Uncommon & Spring \\
$\begin{array}{l}\text { C - Rocky coast, Breach Inlet jetties } \\
\text { G - Composite collection in creeks and sounds in the Town Creek }\end{array}$ & Rare & Spring \\
$\quad$ drainage & & Spring \\
G - Rocky coast, Murrels Inlet jetties & Uncommon & Summer \\
G - Floating dock at Captain Dicks Marina & Rare & Fall \\
\hline
\end{tabular}


Table 2. A sampling of published reports of Polycera hummi from peer-reviewed literature, online museum collections, and community science databases. P. hummi records from museums and online community science databases included photographs of the specimen. $n=$ number of specimens. The reports provided here reflect the regions and common habitats that this species has been collected from previously. It is not a complete list of all published records.

\begin{tabular}{|c|c|c|c|c|c|c|c|}
\hline Type of record & Date of report & Location & Habitat & $n$ & Depth & Size & Source \\
\hline Museum collection & 1951 & Beaufort, NC & - & 5 & - & - & Linsley (1951) \\
\hline Peer-reviewed & 1956 & Beaufort, NC & Oyster reef & 1 & - & - & Marcus (1961) \\
\hline Non-peer-reviewed & $1981-1985$ & $\begin{array}{l}\text { Charleston and } \\
\text { Georgetown, SC }\end{array}$ & Composite (see Table 1) & - & - & - & $\begin{array}{l}\text { Fox and } \\
\text { Ruppert (1985) }\end{array}$ \\
\hline Community science & Nov. 2006 & Morehead City, NC & Upweller in Bogue Sound & 1 & - & $\sim 25 \mathrm{~mm}$ & Fernando (2006) \\
\hline Community science & 8 Nov. 2007 & $\begin{array}{l}\text { Grand Bay National Estuarine } \\
\text { Research Reserve, MS }\end{array}$ & $\begin{array}{l}\text { Floating bryozoans on } \\
\text { muddy saltmarsh edge }\end{array}$ & 1 & $0.5 \mathrm{~m}$ & $\sim 25 \mathrm{~mm}$ & Grammer (2007) \\
\hline Community science & 1 Jun. 2010 & Panacea, FL & Seagrass with sand patches & 1 & $2 \mathrm{~m}$ & $\sim 14 \mathrm{~mm}$ & Grace (2010) \\
\hline Peer-reviewed & 15 Oct. 2020 & $\begin{array}{l}\text { Hurley Reef, Burtons } \\
\text { Bay, VA }\end{array}$ & $\begin{array}{l}\text { Intertidal oyster reef, } \\
\text { associated with Ulva }\end{array}$ & 1 & $\begin{array}{l}\sim 10 \mathrm{~cm} \text { in } \\
\text { tide pool }\end{array}$ & $\sim 12 \mathrm{~mm}$ & This study \\
\hline
\end{tabular}


ESL to Louisiana State University. The Ulva thalli were tightly clumped and damp, but not submerged in seawater during storage prior to shipment, during shipment, or upon arrival. The Ulva thalli were acclimated in a closed-system, 10-gallon aquarium in artificial seawater (Reef Crystals ${ }^{\circledR}$ synthetic salt mix) at $20.5^{\circ} \mathrm{C}$ and $32 \mathrm{ppt}$. The thalli hosted encrusting bryozoans (undetermined genus) and arborescent bryozoans (Bugula sp.), with about $\sim 5 \%$ of the thallus surface occupied. We found a single P. hummi associated with the Ulva sp. thalli. The individual was $\sim 12 \mathrm{~mm}$ in length when the body was extended and had a maximum body width of $\sim 3 \mathrm{~mm}$, excluding papillae and gills. The gill circle was $\sim 2 \mathrm{~mm}$ wide (Fig. 1). We first identified the animal to genus by the characteristic body shape, size, and distinct blue and yellow bands of the papillae (Fig. 1A, D). Further distinguishing features were the paired anterior papillae, the 3-4 papillae present on each side of the posterior gill circle, and the raised yellow crest on the posterior tip of the foot-the distinguishing feature found only on this species (Abbott 1952, Rudman 2006). After photographing and taking morphometric measurements, we preserved the specimen in $100 \%$ ethanol and deposited it in the invertebrate collection at VIMS ESL.

We observed the nudibranch actively move around the tank and on the Ulva during the day, including hanging upside down while locomoting under the surface of the water. After several days in the aquarium, the bryozoans on the Ulva thallus had disappeared. We suspect that the $P$. hummi consumed these bryozoans. Eyster (1980) found 13 adult $P$. hummi and their eggs on floating mats of Bugula sp. Ruppert and Fox (1988) note that P. hummi can be commonly found on Bugula neritina (L.) (Brown Bryozoan), and an unpublished report found a single individual on a floating mat of bryozoans (Table 2). Nudibranchs are regarded as specialized predators, often preying on cnidarians, porifera, bryozoans, ascidians, and other nudibranchs (Hoover et al. 2012, Megina and Cervera 2003, Thompson et al. 1982, Todd and Havenhand 1989). A closely related species, Palio dubia (M. Sars), prefers to
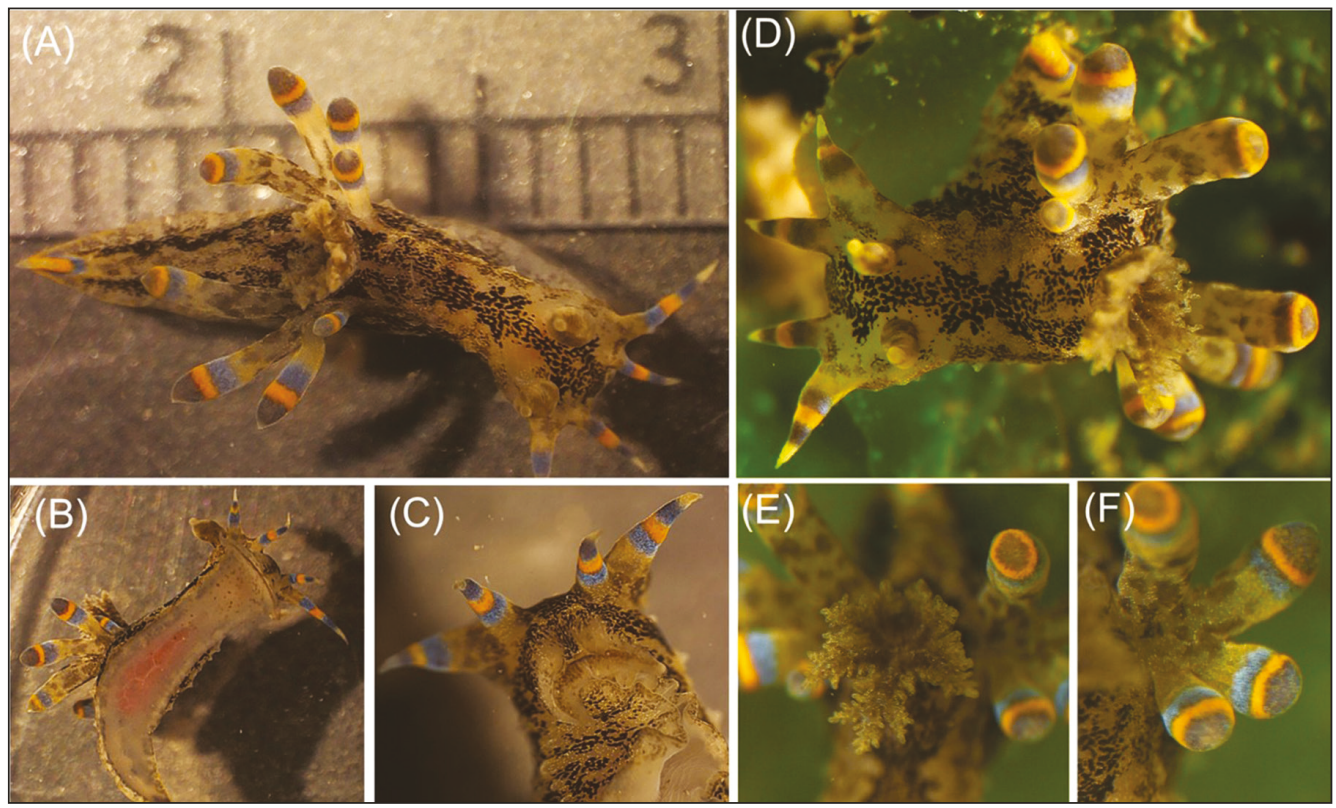

Figure 1. Images of Polycera hummi showing distinctive characteristics. (A) Dorsal view of P. hummi with metric ruler in background (numbers are in $\mathrm{cm}$ ); (B) Ventral view; (C) Ventral view of the mouth and anterior papillae; (D) Dorsal view of P. hummi on Ulva sp.; (E) Dorsal view of gill circle and surrounding papillae; (F) Close up of papillae. 
feed on bryozoans based on multiple-choice experiments and field observations (Hamel et al. 2008). A recent report, however, has demonstrated that a bryozoan-associated species of Polycerella is a micro-herbivore feeding on the periphyton of bryozoans (Camps-Castella et al. 2020). It is likely that $P$. hummi either directly preys on bryozoans or their associated organisms, but further work is required to determine its diet.

This report marks the highest latitude at which $P$. hummi has been found, $\sim 350 \mathrm{~km}$ beyond its previously observed northern limit at Beaufort, NC (Table 2). Additionally, this sighting was $\sim 260 \mathrm{~km}$ north of the biogeographic break near Cape Hatteras, often a barrier to southern subtropical species from moving poleward (Pappalardo et al. 2015). This record may represent a recent range expansion facilitated by changing climate. Temperate and tropical nudibranchs from the Pacific, as well as other taxa from the western subtropical Atlantic, have experienced pole-ward range shifts and expansions attributed to warming sea-surface temperatures (Goddard et al. 2016, Lonhart et al 2019, Nimbs and Smith 2018, Purtelbaugh et al. 2020). Heat-wave events, in particular, have been linked to the expansion of coastal taxa across biogeographic breaks, in addition to reshaping the biotic composition of coastal ecosystems (Fork et al. 2020, Sanford et al. 2019, Wernberg et al. 2013). Smale et al. (2017) documented significant changes in macroinvertebrate composition at moderately and highly warmed sites across the southwestern coast of Australia after the 2011 heatwave. This shift aligned with the reported changes in fish and macroalgae assemblages in the region documented by Wernberg et al. (2013) and Smale et al. (2017). Sea-surface temperatures in the northeast US continental shelf region, which includes the coasts from Cape Hatteras to Nova Scotia, have experienced significant warming in addition to increased frequency of heat-wave events over the past century which have likely facilitated the movements of sub-tropical species northward (Johnson 2015, Mid-Atlantic Regional Ocean Assessment 2021). Data for marine invertebrates are still lacking across many continental margins (Hale et al. 2017, Poloczanska et al. 2016). As upper sea-surface temperatures continue to warm across much of world's coasts in conjunction with more frequent and longer-lasting heat waves (Oliver et al. 2018), it is likely that many marine invertebrates are experiencing unreported range shifts.

Alternatively, due to its elusive nature, the range of $P$. hummi may be larger than previously reported. With the limited reports available for this species, it is difficult to say whether this is an example of climate-mediated range extension or gaps in reporting on this species' true range. It is unlikely that such a charismatic nudibranch would have been misidentified in previous surveys targeting taxonomic enumeration associated with different habitats (e.g., Ross and Snyder 2020). We note that the Ulva thalli were submerged upon collection in a tide pool, but remained emerged in a polyethylene bag during storage prior to and during shipment, suggesting $P$. hummi may be capable of surviving stressful conditions conducive to invading new regions, as in the case of $P$. hedgpethi (Caballer and Ortea 2002, Giacobbe and De Matteo 2013). Additionally, the majority of nudibranch species have a planktotrophic larval stage (Hadfield and Miller 1987). Although larval development in $P$. hummi has not been studied, the larvae of 2 related species, Polycera aurantiomarginata García Gómez \& Bobo and P. quadrilineata (O.F. Müller), are planktonic and may last from days to months in the water column (Martínez-Pita et al. 2006), likely facilitating migration with coastal currents. Future biomonitoring efforts at VIMS ESL will shed light on how rare P. hummi is and whether it is in fact spreading into higher latitudes.

Many simultaneous hermaphroditic invertebrates have the ability to self-fertilize (Leonard 2006), but the prevailing opinion is that nudibranchs are obligate outcrossers (Todd et al. 2001), likely due to self-incompatibility mechanisms (see also Bishop and Pemberton 2006). Yet, our understanding of selfing rates in the sea is limited (Olsen et al. 2020), 
particularly for nudibranchs for which population genetic data characterizing the mating system are rare. For 3 species of Nembrotha, Pola and González Duarte (2008) found specimens in which the penis was located inside the individual's own vagina, leading the authors to speculate on the occurrence of selfing. In the closely related Palio (= Polycera) dubia (M. Sars), exogenous sperm is injected during copulation and exogenous and endogenous sperm may coexist, though it is uncertain whether self-fertilization is possible (Rivest 1984). Our understanding of nudibranch self-incompatibility is largely based on the culture of lone individuals that do not produce progeny in isolation. Without population genetic data, it is not yet possible to determine the mating system of these species, including $P$. hummi. Nevertheless, selfing is not always disadvantageous, such as during range expansions and colonization, and can be advantageous through reproductive assurance (i.e., Baker's Law; Baker 1955). Self-compatibility also commonly evolves at range limits, even in species that are self-incompatible in the center of their ranges (Encinas-Viso et al. 2020). In addition to reproductive assurance, selfing is a trait that can contribute to the persistence of low population density over many generations, leading to chronic rarity (Vermeij and Grosberg 2018). It is curious that nudibranchs are assumed to be obligate outcrossers, considering some nudibranch species can exhibit low population densities across the species range (Fox and Ruppert 1985), especially at the outer edges of species range shifts (Goddard et al. 2016, Nimbs and Smith 2018). However, the disparate data on individual-level variation in reproduction in nudibranchs (e.g., Pola and González Duarte 2008, Todd et al. 2001) hints that there is scope for reproductive system variation (see Barrett 2002 for a review of similar patterns in angiosperms).

Understanding the reproductive mode and other life-history traits of cryptic taxa can be greatly facilitated by the continued operation of community science forums and databases, especially for reporting cryptic species in regions not monitored by marine labs and field stations. Moreover, these databases will be crucial to monitor on-going changes in species distributions.

Acknowledgments. We thank Will Ryan and Edward Smith for help in the field and Linda Ward for help with shipping samples. Data presented here were supported in part by start-up funds from the University of Alabama at Birmingham and the VIMS-ESL Ecological Monitoring Program. We thank Will Ryan for discussions on invertebrate reproductive systems, Morgan Kelly for providing the laboratory space and tools used for processing and preserving the $P$. hummi specimen, as well as providing information regarding nudibranch ecology and for reviewing this manuscript, and Michael Hellberg for reviewing and editing this manuscript and providing useful information regarding bryozoan interactions. We finally thank the anonymous reviewers for comments that improved this manuscript.

\section{Literature Cited}

Abbott, R.T. 1952. Two new opisthobranch mollusks from the Gulf of Mexico belonging to the genera Pleurobranchaea and Polycera. Florida Station University Studies 7:1-7.

Baker, H.G. 1955. Self-compatibility and establishment after "long-distance" dipsersal. Evolution 9:347-348.

Barrett, S.C.H. 2002. Evolution of sex: The evolution of plant sexual diversity. Nature Reviews Genetics 3:274-284.

Behrens, D.W., and A. Hermosillo. 2005. Eastern Pacific Nudibranchs: A Guide to thE Opisthobranchs from Alaska to Central America. Sea Challengers, Monterrey, CA. 137 pp.

Bishop, J.D.D., and A.J. Pemberton. 2006. The third way: Spermast mating in sessile marine invertebrates. Integrative and Comparative Biology 46:398-406.

Caballer, M. and J. Ortea. 2002. Primera cita de Polycera hedgpethi Marcus, 1964 (Mollusca: Opisthobranchia) para la península Ibérica. Noticiario de la Sociedad Española de Malacología $37: 55-56$. 
Calado, G.J., and J.P. Silva. 2012. Lesmas do Mar do Algarve: Guia de Moluscos Opistobrânquios da Costa sul de Portugal. Edições SubNauta, Lisbon, Portugal. $161 \mathrm{pp}$.

Meyer, C. 2010. Polycera hummi. [From Calphotos database; Regents of the University of California, Berkeley, CA.] Available online at https://calphotos.berkeley.edu/cgi/img_query?seq_ num $=91107 \&$ one $=T$. Accessed 4 November 2020 ..

Camps-Castellà, J., M. Ballesteros, R. Trobajo, M. Pontes, and P. Prado. 2020. Not all nudibranchs are carnivorous: Trophic ecology of Polycerella emertoni in the Ebro Delta. Marine Ecology Progress Series 645:67-82.

Debelius, H., and R.H. Kuiter. 2007. Nudibranchs of the World. Ikan-Unterwasserarchiv, Frankfurt, Germany. 360 pp.

Encinas-Viso, F., A.G. Young, and J.R. Pannell. 2020. The loss of self-incompatibility in a range expansion. Journal of Evolutionary Biology 33:1235-1244.

Eyster, L.S. 1980. Distribution and reproduction of shell-less opisthobranchs from South Carolina. Bulletin of Marine Science 30:580-599.

Fernando, A.V. 2006. Polycera hummi from North Carolina. [Message in] Sea Slug Forum. Australian Museum, Sydney. Available online at http://www.seaslugforum.net/find/18476. Accessed 6 November 2020.

Fork, S., B. Pernet, and K. Wasson. 2020. Establishment of an extensive breeding population of a marine pulmonate snail far poleward of its previously documented range. Marine Biodiversity Records 13:5

Fox, R.S., and E.E. Ruppert. 1985. Shallow-water Marine Benthic Macroinvertebrates of South Carolina. University of South Carolina Press, Columbia, SC. 329 pp.

Giacobbe, S., and S. De Matteo. 2013. The potentially invasive opisthobranch Polycera hedgpethi Er. Marcus, 1964 (Gastropoda Nudibranchia), introduced in a Mediterranean coastal lagoon. Biodiversity Journal 4:359-364

Goddard, J.H., N. Treneman, W.E. Pence, D.E. Mason, P.M. Dobry, B. Green, and C. Hoover. 2016. Nudibranch range shifts associated with the 2014 warm anomaly in the Northeast Pacific. Bulletin, Southern California Academy of Sciences 115:15-40.

Gosliner, T.M. 1980. A new record of the nudibranch gastropod Polycera hedgpethi Marcus, from the Indian Ocean of South Africa. Journal of Molluscan Studies 48:30-35.

Grace, K.L., 2010. Polycera hummi from Gulf of Mexico. [Message in] Sea Slug Forum. Australian Museum, Sydney. Available online at http://www.seaslugforum.net/find/23687. Accessed 6 November 2020].

Grammer, G.L. 2007. Polycera hummi from Mississippi, USA . [Message in] Sea Slug Forum. Australian Museum, Sydney. Available online at http://www.seaslugforum.net/find/21151. Accessed 6 November 2020.

Hadfield M.G., and S.E. Miller. 1987. On developmental patterns of opisthobranchs. American Malacological Bulletin 1:197-214

Hale S.S., H.W. Buffum, J.A. Kiddon, and M.M. Hughes. 2017. Subtidal benthic invertebrates shifting northward along the US Atlantic Coast. Estuaries and Coasts 40:1744-56.

Hamel, J.-F., P. Sargent, and A. Mercier. 2008. Diet, reproduction, settlement, and growth of Palio dubia (Nudibranchia: Polyceridae) in the northwest Atlantic. Journal of the Marine Biological Association of the United Kingdom 88:365-374.

Hoover, R.A., R. Armour, I. Dow, \& J.E. Purcell. 2012 Nudibranch predation and dietary preference for the polyps of Aurelialabiata (Cnidaria: Scyphozoa). Hydrobiologia 690:199-213.

iNaturalist. 2019a.Polycera hummi [research grade]. Available online at https://www.inaturalist.org/ observations/22371093. Accessed 1 November 2020.

iNaturalist. 2019b.Polycera hummi [research grade]. Available online at https://www.inaturalist.org/ observations/41028010. Accessed 1 November 2020.

Johnson, D.S. 2015. The savory swimmer swims north: A northern range extension for the Blue Crab, Callinectes sapidus? Journal of Crustacean Biology 35:105-110.

Krueger-Hadfield, S., T.A. Stephens, W.H. Ryan, and S. Heiser. 2018. Everywhere you look, everywhere you go, there's an estuary invaded by the red seaweed Gracilaria vermiculophylla (Ohmi) Papenfuss, 1967. BioInvasions Records 7:343-355. 
Leonard, J.L. 2006. Sexual selection: Lessons from hermaphrodite mating systems. Integrative and Comparative Biology 46:349-367.

Linsley, R.M. 1951. Polycera hummi [Record from the Smithsonian National Museum of Natural History Collections Invertebrate Zoology Department database.] Available online at https://collections.si.edu/search/detail/edanmdm:nmnhinvertebratezoology_422345?q=Polycera+hummi\& record=6\&hlterm=Polycera\%2Bhummi. Accessed March 2021.

Lonhart, S.I., R. Jeppesen, R. Beas-Luna, J.A. Crooks, and J. Lorda. 2019. Shifts in the distribution and abundance of coastal marine species along the eastern Pacific Ocean during marine heatwaves from 2013 to 2018. Marine Biodiversity Records 12:1-15

Marcus, E. 1961. Opisthobranchia from North Carolina. Journal of the Elisha Mitchell Scientific Society $77: 141-51$.

Marshall, B., P. Bouchet, and S. Gofas. 2020. Polycera Cuvier, 1816. World Register of Marine Species. https://www.marinespecies.org/aphia.php? $\mathrm{p}=$ taxdetails\&id=138369. Accessed 8 November 2020.

Martínez-Pita, I., A.I. Sánchez-España, and F.J. García. 2006. Some aspects of the reproductive biology of two Atlantic species of Polycera (Mollusca: Opisthobranchia). Journal of the Marine Biological Associations of the United Kingdom 86:391-399.

Megina, C., and J.L. Cervera. 2003. Diet, prey selection and cannibalism in the hunter opisthobranch Roboastra europaea. Journal of the Marine Biological Association of the United Kingdom 83:489-495.

Mid-Atlantic Regional Ocean Assessment. 2021. Ecosystem responses to climate change.Available online from https://roa.midatlanticocean.org/ocean-ecosystem-and-resources/characterizing-themid-atlantic-ocean-ecosystem/ecosystem-responses-to-climate-change/. Accessed 10 February 2021.

Nimbs, M.J., and S.D. Smith 2018. Beyond Capricornia: Tropical sea slugs (Gastropoda, Heterobranchia) extend their distributions into the Tasman Sea. Diversity 10:99.

Mudgett, K. 2004. Polycera hummi from Florida. [Message in] Sea Slug Forum. Australian Museum, Sydney. Available online from http://www.seaslugforum.net/find/11853. Accessed 6 November 2020.

Oliver, E.C.J., M.G. Donat, M.T. Burrows, P.J. Moore, D.A. Smale, L.V. Alexander, J.A. Benthuysen, M. Feng, et al. 2018. Longer and more frequent marine heatwaves over the past century. Nature Communications 9:1.

Olsen, K.C., W.H. Ryan, A.A. Winn, E.T. Kosman, J.A. Moscoso, S.A. Krueger-Hadfield, S.C. Burgess, D.B. Carlon, R.K. Grosberg, S. Kalisz, D.R. Levitan. 2020. Inbreeding shapes the evolution of marine invertebrates. Evolution 74:871-882.

Ortea, J., J. Espinosa, and Y. Camacho. 1999. Species of the genus Polycera Cuvier, 1816 Mollusca Nudibranchia collected from red algal epifauna in the Caribbean of Costa Rica and Cuba Especies del genero Polycera Cuvier, 1816 Mollusca Nudibranchia recolectadas en la epifauna de algas rojas del Caribe de Costa Rica y Cuba. Avicennia 1011:157-64.

Pappalardo, P., J.M. Pringle, J.P. Wares, and J.E. Byers. 2015. The location, strength, and mechanisms behind marine biogeographic boundaries of the east coast of North America. Ecography 38:722-731.

Pola, M., and M.M. González Duarte. 2008. Is self fertilization possible in nudibranchs? Journal of Molluscan Studies 74:305-308.

Pola, M., M. Sánchez-Benítez, and B. Ramiro. 2014. The genus Polycera Cuvier, 1817 (Nudibranchia: Polyceridae) in the eastern Pacific Ocean, with redescription of Polycera alabe Collier \& Farmer, 1964 and description of a new species. Journal of Molluscan Studies 80:551-61.

Poloczanska, E.S., M.T. Burrows, C.J. Brown, J. García Molinos, B.S. Halpern, O. Hoegh-Guldberg, C.V. Kappel, P.J. Moore, A.J. Richardson, D.S. Schoeman, and W.J. Sydeman. 2016. Responses of marine organisms to climate change across oceans. Frontiers in Marine Science 3:62.

Purtlebaugh, C.H., C.W. Martin, and M.S. Allen. 2020. Poleward expansion of common snook Centropomus undecimalis in the northeatern Gulf of Mexico and future research needs. PLoS one 15:e0234083. https://doi.org/10.1371/journal.pone.0234083. 
Rivest, B.R. 1984. Copulation by hypodermic injection in the nudibranchs Palio zosterae and P. dubia (Gastropoda, Opisthobranchia). The Biological Bulletin 167:543-54.

Ross, P.G., and R.A. Synder. 2020. Ecological Monitoring Program at VIMS ESL - Annual Report 2018-2019. Virginia Institute of Marine Science, William \& Mary. Available online at https:// scholarworks.wm.edu/reports/2090. Accessed 1 December 2020..

Rudman, W.B.. 2004. Polycera hummi Abbott, 1952. In Sea Slug Forum. Australian Museum, Sydney. Available online at http://www.seaslugforum.net/find/polyhumm. Accessed 6 November 2020.

Rudman, W.B. 2006. Comment on Re: Polycera hummi from North Carolina by Anthony Fernando. [Message in] Sea Slug Forum. Australian Museum, Sydney. Available online at http://www.seaslugforum.net/find/18699. Accessed 6 November 2020.

Ruppert, E.E., and R.S. Fox. 1988. Seashore Animals of the Southeast: A Guide to Common Shallowwater Invertebrates of the Southeastern Atlantic Coast. University of South Carolina Press, Columbia, SC. 429 pp.

Sanford, E., J.L. Sones, M. García Reyes, J.H.R. Goddard, and J.L. Largier. 2019. Widespread shifts in the coastal biota of northern California during the 2014-2016 marine heatwaves. Scientific Reports 9:1-14.

Smale, D., T. Wernberg, and M. Vanderklift. 2017. Regional-scale variability in the response of benthic macroinvertebrate assemblages to a marine heartwave. Marine Ecology Progress Series 568:17-30

Steinhagen, S., R. Karez, and F. Weinberger. 2019a. Cryptic, alien, and lost species: Molecular diversity of Ulva sensu lato along the German coasts of the North and Baltic Seas. European Journal of Phycology 54:466-483

Steinhagen, S., F. Weinberger, and R. Karez. 2019b. Molecular analysis of Ulva compressa (Chlorophyta, Ulvales) reveals its morphological plasticity, distribution, and potential invasiveness on German North Sea and Baltic Sea coasts. European Journal of Phycology 54:102-114.

Thompson, J.E., R.P., Walker, S.J. Wratten, and D.J. Faulkner. 1982. A chemical defense mechanism for the nudibranch Cadlina luteomarginata. Tetrahedron 38:1865-1873

Todd, C.D., and J.N. Havenhand. 1989. Nudibranch-bryozoan associations: The quantification of ingestion and some observations on partial predation among Doridoidea. Journal of Molluscan Studies 55:245-529.

Todd, C.D., W.J. Lambert, and J. Davies. 2001. Some perspective on the biology and ecology of nudibranch molluscs: gGneralisations and variations on the theme that prove the rule. Bollettino Malacologico, Roma 37:105-120.

Vermeij, G.J., and R.K. Grosberg. 2018. Rarity and persistence. Ecology Letters 21:3-8.

Wernberg, T., D. Smale, F. Tuya, M.S. Thomsen, T.J. Langlois, T. De Bettignies, S. Bennett, and C.S. Rousseaux. 2013. An extreme climatic event alters marine ecosystem structure in a global biodiversity hotspot. Nature Climate Change 3:78-82.

Wilson, N. 2006. New record of the nudibranch Polycera hedgpethi Er. Marcus, 1964, in South Australia, with a discussion on its occurrence in Australia. Records of the Western Australian Museum 69:137-140. 